\title{
CINDERELLA COMPLEX DALAM PERSPEKTIF PSIKOLOGI PERKEMBANGAN SOSIAL EMOSI
}

\author{
Tsurayya Syarif Zain \\ Mahasiswa pasca sarjana Fakultas Psikologi Universitas Gadjah Mada \\ tsyrayyasyarif@gmail.com
}

\begin{abstract}
Cinderella Complex is the tendency of women to depend psychically, which is shown by their strong desire to be treated and protected other people, especially men, as well as the belief that one of the outsider who would help him. This article aims to explain cinderella complex in the perspective of psychology in social and emotional development. It also viewed how determinants Cinderella Complex. Based on the assessment results from different sources about the appearance of Cinderella Complex in a woman's self can not be separated from their influencing factors, among others: Pattern foster parent, Personal Maturity and Self-Concept. In the perspective of gender development, Cinderella Complex in women is influenced by the local culture that perceive women as weak and can not be independent.
\end{abstract}

Keywords: Cinderella Complex, factors, developmental psychology

\begin{abstract}
Abstraksi. Cinderella Complex adalah kecenderungan perempuan untuk tergantung secara psikis, yang ditunjukan dengan adanya keinginan yang kuat untuk dirawat dan dilindungi orang lain terutama laki-laki, serta keyakinan bahwa suatu dari luarlah yang akan menolongnya. Artikel ini bertujuan untuk menjelaskan cinderella complex dalam perspektif psikologi dalam perkembangan sosial dan emosional. Selain itu juga melihat bangaimana faktor-faktor penentu Cinderella Complex. Berdasarkan hasil pengkajian dari berbagai sumber mengenai Cinderella Complex munculnya Cinderella complex pada diri seorang perempuan tidak terlepas dari adanya faktor-faktor yang mempengaruhinya antara lain: Pola asuh orang tua, Kematangan Pribadi, dan Konsep Diri. Dalam perspektif perkembangan gender, Cinderella Complex pada perempuan dipengaruhi oleh budaya setempat yang mempersepsikan perempuan sebagai makhluk yang lemah dan tidak bisa mandiri.
\end{abstract}

Kata kunci: Cinderella Complex, faktor-faktor, psikologi perkembangan

\section{PENDAHULUAN}

Cerita cinderella merupakan dongeng tradisional dengan versi yang dijumpai di berbagai belahan dunia dengan berbagai macam variasi. Cinderella merupakan dongeng menceritakan tentang gadis cantik dan baik hati yang tinggal bersama ibu tiri dan kedua saudara tirinya. Selama tinggal bersama mereka Cinderella mengalami berbagai macam penyiksaan dan kehidupanya berubah menjadi sempurna ketika seorang pangeran yang menemukan sepatu kacanya menikahinya hingga akhirnya kehidupanya berakhir bahagia.
Cerita Cinderella dijadikan sebagai istilah yang diperkenalkan oleh psikiater Colette Dowling dengan istilah Cinderella complex. Colette Dowling dalam sebuah buku berjudul "The Cinderella Complex: Women's Hidden Fear of Independence" merujuk pada kecenderungan perempuan untuk tergantung secara psikis, yang ditunjukan dengan adanya keinginan yang kuat untuk dirawat dan dilindungi orang lain terutama laki-laki, serta keyakinan bahwa suatu dari luarlah yang akan menolongnya.

Elly Risman menyebutkan orang tua yang menerapkan pola asuh yang membiasakan 
anak hidup nyaman, tidak dibebankan pada tugas rumah, ketika anak diganggu teman orang tua cenderung langsung turun tangan, bisa jadi anak kelak akan tumbuh layaknya Cinderella, tokoh perempuan yang digambarkan sebagai seorang yang cantik dan baik hati dan dikisahkan berakhir dalam kisah yang bahagia. Disadari atau tidak, orang tua telah menjerumuskan buah hati pada pola asuh, bacaan atau tontonan, seperti dongeng Cinderella, Barbie, dan princess lainya, membiarkan menonton sinetron yang menjual mimpi, tanpa adanya pengarahan. Secara tidak langsung dongeng tersebut terekam dalam otak bahkan hingga sampai pada tahap obsesi. Cinderella Complex (CC) dapat menimbulkan katakutan tersembunyi pada perempuan untuk hidup susah dan mandiri (Majalah Ummi, 2010).

Dalam kasus Cinderella Complex, cerita dongeng yang diceritakan pada anak tanpa adanya arahan menjadikan anak mempersepsikan cerita kedalam kehidupan penuh impian yang akan berakhir bahagia. Namun, dalam penelitian lain kisah dongeng Cinderella memiliki unsur dasar yang secara alami mampu membuka pemahaman psikilogis klien dimana dongeng bisa menjadi penyembuhan yang tepat untuk membantu klien dalam menempatkan narasi mereka ke dalam konteks yang lebih besar dari penderitaan manusia, dan dengan demikian membuat proses alkimia individuasi lebih tertahankan. Oleh karena itu, diperlukan kajian secara menyeluruh bagaimana kisah dongeng termasuk kisah Cinderella mampu memanifestasi perkembangan psikologis anak kedalam konteks yang lebih luas.

Dalam hal ini, penulis mencoba menguraikan beberapa literatur terkait Cinderella Complex dan efeknya yang direpresentasikan dalam kajian psikologi perkembangan beserta keterkaitanya dalam proses sosial emosi.

\section{Pengertian Cinderella Complex}

Cinderella Complex merupakan suatu jaringan sikap dan rasa takut yang sangat tertekan sehingga wanita tidak bisa dan tidak berani memanfaatkan sepenuhnya kemampuan otak dan kreativitasnya(Dowling, 1995). Symonds (dalam Fitriani dkk, 2013) menyatakan bahwa masalah Cinderella Complex merupakan masalah dari hampir semua perempuan yang pernah ditemuinya. Para perempuan yang tampak dari luar sangat berhasil juga cenderung menjadi tergantung dan tanpa sadar mengabdikan sebagian besar energi mereka untuk mendapatkan cinta, pertolongan dan perlindungan terhadap apa yang kelihatannya sulit dan menantang di dunia..

Dowling juga menjelaskan bahwa cinderellacomplexmerupakanketergantungan psikologis pada perempuan dimana terdapat keinginan yang mendalam untuk dirawat dan dilindungi oleh orang lain terutama lakilaki. Dowling (1995) menjelaskan bahwa cinderella complex biasanya menyerang gadis-gadis enam belas tahun atau tujuh belas tahun, kerap kali menghalangi mereka dari pergi melanjutkan pendidikan, mempercepat mereka memasuki pernikahan usia muda. Cinderella complex juga cenderung menyerang wanita yang sudah menempuh pendidikan tinggi. Selain itu, dalam penelitian yang dilakukan psikolog Elizabeth Douvan, bahwa sampai usia delapan belas tahun (dan kadang-kadang lebih) para gadis sungguhsungguh tidak memperlihatkan gerak ke arah kemandirian (Dowling, 1995).

$\mathrm{Su}$ (2010) memaparkan bahwa kisah Cinderella merupakan kisah tradisonal yang memiliki lebih dari 700 versi dan 
diceritakan di berbagai negara dan budaya. Di Indonesia sendiri, kisah Cinderella memiliki konten yang serupa dengan kisah Bawang Merah dan Bawang Putih. Cerita tersebut secara umum diintepretasikan pada kurangnya kekuasaan wanita pada zaman dahulu dan rendahnya status sosial mereka di masyarakat menyebabkan perasaan tidak berdaya. Perasaan tidak berdaya ini yang menempatkan perempuan pada resiko depresi yang menjadikan wanita mengalami cinderella complex.

\section{Faktor yang Mempengaruhi Cinderella Complex}

Dowling (1995) menyebutkan munculnya Cinderella complex pada diri seorang perempuan tidak terlepas dari adanya faktorfaktor yang mempengaruhinya antara lain:

1) Pola asuh orang tua.

Pola asuh orang tua menjadi salah satu faktor yang penting dalam membentuk kepribadian anak sejak dini. Kemandirian pada individu berpusat pada ego atau diri sebagai dimensi pemersatu yang mengorganisasikannya menjadi sebuah kepribadian. Kecenderungan yang muncul di permukaan dewasa in ditunjang oleh pola asuh orang tua. Pola asuh orang tua dalam suatu keluarga akan mempengaruhi kemandirian pada diri anak khususnya perempuan.

Pola asuh permisif orang tua memegang peranan penting dalam pembentukan kecenderungan cinderella complex pada anak. Sikap permisif orang tua yang ada akan berbanding terbalik dengan kecenderungan cinderella complex, karena makin tinggi persepsi pola asuh permisif yang terbentuk, makin rendah kecenderungan cinderella complex yang terjadi pada anak. Sikap permisif yang timbul, kelonggaran danperaturan yang tidak ketat serta adanya kebebasan dalam menentukan keputusan akan mengakibatkan anak berkembang menjadi pribadi yang mandiri.

Menurut Saha (2016) Bagi wanita yang menderita Cinderella yang tipe kompleks, ketergantungan dan rendah diri tampaknya menjadi akar penyebab masalah. Kebanyakan psikolog percaya bahwa dalam banyak kasus masalah ketergantungan mungkin akibat dari orangtua sangat over-protektif. Bahkan, orang tua ini mungkin telah meningkat perilaku pelindung normal menjadi pengendali kasar, dalam beberapa kasus bahkan menghukum anak untuk menampilkan tanda-tanda kemerdekaan. Hal ini juga dianggap kemungkinan bahwa wanita yang menderita kompleks ini dipermalukan secara sosial selama tahun-tahun formatif mereka, yang sering menjadi penyebab harga diri yang rendah.

Penelitian yang dilakukan oleh Fitriani, dkk (2013) menyimpulkan bahwa ada hubungan negatif yang signifikan antara persepsi pola asuh permisif orang tua dengan cinderella complex pada siswi SMK Negeri 1 Gebang. Hubungan negatif ini berarti sesuai dengan hipotesis yang diajukan bahwa makin positif persepsi pola asuh permisif orang tua maka makin rendah cinderella complex pada siswi SMK Negeri 1 Gebang, sebaliknya makin negatif persepsi pola asuh permisif orang tua maka makin tinggi cinderella complex pada siswi SMK Negeri 1 Gebang.

2) Kematangan Pribadi

Menurut George (2006), kematangan merupakan proses terus-menerus sebuah sistem organisme dalam mencapai kedewasaan kelakuan, yang memantapkan reaksi-reaksi organisme terhadap alam sekitar sedemikian 
rupa, sehingga menjadi mampu mempertahankan keutuhan organisme sesuai dengan keadaan dewasa, yang dihasilkan dari proses pemasakan. Faktorfaktor yang mempengaruhi kematangan kepribadian menurut Schneider (dalam Iswatiningrum, 2013) sebagai berikut

a. Kondisi fisik, meliputi hereditas, keadaan fisik,kesehatan, penyakit dan lain-lain.

b. Perkembangan dan kematangan, khususnya kematangan intelektual, sosial, moral, dan emosional.

c. Faktor-faktor psikologis, meliputi pengalaman, frustasi, maupun konflik.

d. Kondisi lingkungan.

e. Faktor budaya, meliputi adat.

Keyakinan yang tumbuh di dalam kematangan kepribadian perempuan dinilai orang lain berdasarkan persepsi yang dimilikinya dan dipengaruhi oleh lingkunganserta pribadiyang tidak matang mengakibatkan perempuan mengalami kecenderungan cinderellacomplex. Kecenderungan cinderella complex akan berpengaruh terhadap cara perempuan berinteraksi dengan lingkungannya dan ketika menghadapi kesempatan untuk mengembangkan diri serta dalam menghadapi permasalahan.

Penelitian yang dilakukan oleh Iswatiningrum (2013) mengenai hubungan kematangan pribadi dengan kecenderungan Cinderella Complex menyimpulkan bahwa terdapat hubungan negatif antara kematangan kepribadian dengan kecenderungan cinderella complex pada Mahasiswa di Asrama Putri Universitas Negeri Surabaya, artinya semakin tinggi kematangan kepribadian maka semakin rendah kecenderungan cinderella complexpada Mahasiswa di Asrama Putri Universitas Negeri Surabaya. Begitu juga sebaliknya, semakin rendah Kematangan Kepribadian maka semakin tinggi kecenderungan cinderella complex pada Mahasiswa di Asrama Putri Universitas Negeri Surabaya.

3) Konsep Diri.

Calhoun \& Acocella (dalam Wulandari, 2010) menyatakan bahwa individu yang memiliki konsep diri yang negatif akan memiliki penilaian negatif terhadap dirinya sehingga merasa bahwa dirinya tidak cukup berharga dibandingkan orang lain. Individu yang memiliki konsep diri yang positif akan memiliki penilaian yang positif terhadap dirinya sehingga dapat menerima dirinya sendiri secara apa adanya.

Effendi (dalam Dewi dkk, 2004) menyatakan bahwa konsep diri antara laki-laki dan perempuan berbeda karena perlakuan orang lain yang berbeda, karena perlakuan masyarakat atau lingkungan terhadap laki-laki dan perempuan. Keyakinan yang tumbuh di dalam konsep diri perempuan tentang stereotipe yang diinternalisasikan dan disosialisasikan lingkungan serta harga diri yang rendah mengakibatkan perempuan mengalami kecenderungan CinderellaComplex. Kecenderungan Cinderella Complex akan berpengaruh terhadap cara perempuan berinteraksi dengan lingkungannya dan ketika menghadapi kesempatan untuk mengembangkan diri serta dalam menghadapi permasalahan.

Penelitian yang dilakukan oleh Wulandari (2010) mengenai hubungan konsep diri dengan kecenderungan Cinderella Complex menyimpulkan bahwa terdapat hubungan negatif antara 
konsep diri dengan kecenderungan Cinderella Complex pada mahasiswa Fakultas Psikologi Universitas Diponegoro Semarang. Tanda negatif mengindikasikan semakin positif konsep diri, maka semakin rendah tingkat kecenderungan Cinderella Complex pada mahasiswa. Sebaliknya semakin negatif konsep diri, maka semakin tinggi kecenderungan Cinderella Complex pada mahasiswa. Konsep diri memberikan sumbangan efektif sebesar 49,6\% terhadap kecenderungan Cinderella Complex mahasiswa Fakultas Psikologi Universitas Diponegoro Semarang. Sumbangan efektif sebesar $49,6 \%$ ini mengindikasikan bahwa konsep diri berpengaruh dalam kecenderungan Cinderella Complex dalam diri mahasiswa perempuan, sedangkan sisanya sebesar $50,4 \%$ ditentukan oleh faktor-faktor lain yang tidak diungkap dalam penelitian ini.

\section{Cinderella Complex dalam Pandangan Perkembangan Psikoanalisis}

Marks (2013) dalam tesis heuristik yang berjudul Transforming Cinderella: A Fairy Tale of Individuation mencoba untuk mengeksplorasi dongeng sebagai metafora pola dasar yang menggambarkan proses pergerakan individuasi-jiwa terhadap keutuhan diri. Dalam penelitian ini Marks berupaya memberikan kontribusi pada bidang konseling dan kedalaman psikoterapi dengan menyediakan contoh menafsirkan dan menggunakan dongeng masa kecil sebagai metafora untuk perjalanan individuasi. Tujuan terakhir pemekaran ini adalah realisasi diri. Untuk memiliki kepribadian yang sehat dan terintegrasi, setiap sistem harus dibiarkan mencapai tingkat diferensiasi, perkembangan, dan pengungkapan yang paling penuh. Proses untuk mencapai ini disebut proses individuasi.
Kisah dongeng anak cinderelladan kaitanya dengan perkembangan sosial dan emosional, merupakan kisah yang Carl G Jung intepretasikan dalam konstruk psikologis yaitu Persona. Stein (dalam Marks, 2013) menjelaskan persona adalah konstruk psikologis yang timbul dari kebutuhan untuk menyesuaikan diri dan beradaptasi dengan lingkungan fisik dan sosial. Hal tersebut mulai terbentuk pada anak usia dini dalam menanggapi harapan orang tua, guru, dan teman sebaya. Persona diibaratkan sebagai topeng publik satu memakai bisa diterima dunia. Sedangkan persona memegang ciri diterima, yang tidak diinginkan ditekan, mengingkari, dan diturunkan ke ketidaksadaran pribadi, di mana mereka bergabung untuk membentuk struktur kebalikannya dalam jiwa: bayangan. Karena tujuan dari perkembangan psikologis adalah integrasi, hubungan ego untuk bayangan, persona, dan Self berjalan melalui perubahan besar pada pertengahan kehidupan.

Carl G. Jung menemukan konsep ini dari mitos pribadi. Melalui mitos individual, Jung menyebutkan munculnya mitos kolektif baru sebagai mitos penciptaan kesadaran. Hal ini pada akhirnya kisah Cinderella (Grimm \& Grimm, 1812/1944) menjadi sebuah cerita simbolik terdalam dan pembesaran kesadaran yang terjadi di dalam dan melalui proses individuasi. Perkembangan adalah mekarnya kebulatan asli yang tidak berdiferensiasi yang dimiliki manusia pada saat dilahirkan. Kedalaman interpretasi psikologis dari kisah Cinderella dijadikan sebagai contoh dari cerita arketipe (inisiasi pola dasar) dari ketidaksadaran kolektif, yang berfungsi sebagai proses intrapsikis yang menghubungkan ego dengan keutuhan diri. Dengan menekankan potensi penyembuhan tertanam dalam cerita pola dasar seperti Cinderella, penelitian ini berfungsi sebagai 
panduan bagi dokter dan individu untuk membantu menavigasi gangguan psikis pada diri seseorang yang melekat dalam pertumbuhan psikologisnya.

Menurut Freud (dikutip Lips, 2005,) menyebutkan perempuan merasa inferior bukan karena internalisasi dan sosialisasi gender dari lingkungannya. Selama tahap falik yaitu pada usia 3-6 tahun, perkembangan identifikasi gender pada laki-laki dan perempuan berbeda. Pada perempuan, identifikasi feminin itu dimulai ketika anak perempuan mengalami kecemburuan terhadap penis karena tidak memiliki penis seperti halnya laki-laki. Anak perempuan merasa inferior lalu menyalahkan ibunya dan menarik afeksi dari ibunya sehingga menjadikan ayahnya sebagai objek cinta. Anak perempuan kemudian menyadari bahwa dia tidak akan memiliki ayahnya sehingga menyusun kembali identifikasi feminin dengan ibunya dan mencoba menjadi objek cinta bagi laki-laki.

\section{Cinderella Complex dalam Perspektif Perkembangan Gender}

Cinderella Complex terbentuk berawal dari perbedaan perlakuan yang diterima oleh anak perempuan dan anak laki-laki ketika kecil. Sejak kecil anak perempuan mendapatkan dispensasi secara tidak langsung dalam hal kemandirian. Pria dididik untuk menjadi mandiri sejak hari mereka dilahirkan dengan cara yang sama sistematisnya, wanita diajarakan untuk tidak dikhawatirkan kepada permasalahan yang besar, sedangkan pria dituntut untuk bisa melakukan berbagai macam hal. Namun hal tersebut dipengaruhi oleh bagaimana budaya mempengaruhi stereotipe dalam membedakan anatara lakilaki dan perempuan (Vargheze, 2015).

Shaffer (2009) menyebutkan bahwa standar peran gender masyarakat menjelaskan bagaimana pria dan wanita diharapkan untuk berperilaku, dan mencerminkan stereotip bersama mengenai laki-laki dan perempuan. Munculnya Cinderella Complex pada perempuan dipengaruhi oleh budaya setempat yang mempersepsikan perempuan sebagai makhluk yang lemah dan tidak bisa mandiri. Penelitian Barry, Bacon, dan Irving (1957) pada 110 masyarakat non industry untuk mencari perbedaan lakilaki dan perempuan dalam hal sosialisasi. Terdapat lima atribut dalam penelitian, yaitu prestasi dan kemandirian (mewakili sosok laki-laki); mengasuh, tanggung jawab, taat (merepresentasikan perempuan). Tidak berarti perempuan yang mandiri dan lakilaki yang taat tidak akan diterima, namun kelima atribut tersebut hanya dianggap dapat menjadi representasi dari jenis kelaminnya. Namun, penelitian pada orang tua di Barat memberikan penekanan yang kurang lebih sama pada prestasi untuk anak laki-laki maupun perempuan (Lytton \& Romney, dalam Shaffer, 2009).

\section{SIMPULAN}

Dowling juga menjelaskan bahwa cinderellacomplexmerupakanketergantungan psikologis pada perempuan dimana terdapat keinginan yang mendalam untuk dirawat dan dilindungi oleh orang lain terutama lakilaki. Munculnya Cinderella complex pada diri seorang perempuan tidak terlepas dari adanya faktor-faktor yang mempengaruhinya antara lain: Pola asuh orang tua, Kematangan Pribadi, dan Konsep Diri.

Berdasarkan perspektif Psikoanalisis, Cinderella Complex terjadi ketika perempuan merasa inferior bukan karena internalisasi dan sosialisasi gender dari lingkungannya. Selama tahap falik yaitu pada usia 3-6 tahun, perkembangan identifikasi gender pada lakilaki dan perempuan berbeda. Cinderella 
Complex terbentuk pada anak usia dini perspektif perkembangan gender, Cinderella dalam menanggapi harapan orang tua, guru, dan teman sebaya, ketika masyarakat dalam lingkungan budaya tersebut mempersipkan perempuan sebagai makhluk yang lemah Complex pada perempuan dipengaruhi oleh budaya setempat yang mempersepsikan perempuan sebagai makhluk yang lemah dan dan perlu membutuhkan pertolongan. Dalam tidak bisa mandiri.

\section{DAFTAR PUSTAKA}

Dowling, Colette. 1995. Tantangan Wanita Modern : Ketakutan Wanita akan Kemandirian. Alih bahasa: Santi, W.E., Soekanto. Jakarta: Erlangga.

Hapsari, Annisa. 2014. Cinderella Complex Pada Mahasiswi di Universitas Negeri Semarang. Developmental and Clinical Psychology 3 (1) (2014).Http//Journal.uness.ac.id

Iswantiningrum, Febritania. 2013. Hubungan Antara Kematangan Kepribadian Dengan Kecenderungan Cinderella Complex Pada Mahasiswa Di Asrama Putri universitas Negeri. Jurnal Mahasiswa Psikologi Volume 02 Nomor 01 Tahun 2013

Marks, Carol. 2013. Transforming Cinderella: A Fairy Tale of Individuation. Dissertation Publishing. UMI Number: 1524868

Miller, 1. 2008. Japan's cinderella motif : Beauty Industry And Mass Culture Interpretations of A Popular Icon. Asian studies review. Vol.32.393-409.

Saha, Sneha, et al. 2016. Cinderella Complex: Theoretical Roots to Psychological Dependency Syndrome in Women. The International Journal of Indian Psychology ISSN 2348-5396 (e) | ISSN: 2349-3429 (p) Volume 3, Issue 3, No. 8, DIP: 18.01.148/20160303 ISBN: 978-1-365-12176-0

Shaffer, David. 2009. Social and Personality Development, Sixth Edition. USA: Wadsworth

Su, Tiping. 2012. The Analysis of Transition in Woman Social Status-Comparing Cinderella with Ugly Betty. Journal of Language Teaching and Research. Vol.1. No.5. Hlm.746752.

Wulansari, sapti. 2010. Hubungan antara konsep diri dengan Kecenderungan Cinderella Complex. Skripsi Fakultas Psikologi Universitas Diponegoro. Semarang

Vargheze, Lata. 2015. De-Mythologizing the 'Cinderella Complex': Jaishree Misra's Ancient Promise. The Criterion: An International Journal In English ISSN: 0976-8165 